Anna Kleiber

Biblioteka Raczyńskich w Poznaniu e-mail: a_kleiber@poczta.onet.pl

\title{
Struktura wypożyczeń książek oraz udostępnień zbiorów naukowych w Bibliotece Raczyńskich w latach 2000-2010
}

STRESZCZENIE: W artykule przedstawiono analizę wypożyczeń książek beletrystycznych i niebeletrystycznych wypożyczanych przez czytelników dorosłych oraz czytelników do lat 15, a także strukturę udostępnień zbiorów naukowych w Bibliotece Raczyńskich w latach 2000-2010. Wykazano, że w obydwu badanych grupach większym zainteresowaniem cieszyły się książki beletrystyczne niż niebeletrystyczne.

SŁowA KLUCzowE: analiza wypożyczeń, Biblioteka Raczyńskich, książki beletrystyczne, książki niebeletrystyczne, udostępnianie zbiorów naukowych

\section{Wprowadzenie}

Cemp zy czytanie jest ważne? Wszyscy wiemy, że tak. Lektura uczy dzieci empatii, skłania do namysłu, wyjaśnia rzeczywistość ${ }^{1}$, a w przyszłości umożliwia także nadążenie za rozwijającym się społeczeństwem informacyjnym. Czytelnicy dorośli szukają w książkach między innymi informacji oraz rozrywki. Niestety, w ostatnich latach nastąpił spadek czytelnictwa, dodatkowo pogłębiany przez rosnące ceny książek. Dlatego najpopularniej-

${ }^{1}$ Siedemnaście zalet czytania książki [on-line]. Miejska Biblioteka Publiczna im. H. Sienkiewicza w Płońsku [dostęp 15 kwietnia 2012]. Dostępny w World Wide Web: http://www.mbp-plonsk.pl/pagedet/index/id/68/17_zalet_czytania_ksiazki.html. 
szym ich źródłem stają się biblioteki (40\%), zwłaszcza publiczne $(27 \%)^{2}$. A po jakie książki najchętniej sięgają Polacy? Według badań z 2006 r. aż 73\% polskich czytelników książek preferowało literaturę piękną ${ }^{3}$.

W celu określenia, po jakiego typu książki najczęściej sięgają czytelnicy korzystający z zasobów Biblioteki Raczyńskich (dalej: BR), przeanalizowano dane z lat 2000-2010 uwzględniające: wypożyczenia książek beletrystycznych oraz niebeletrystycznych w filiach BR oraz udostępnienia zbiorów naukowych.

\section{Metodyka badań}

Przedstawione w niniejszym artykule wyniki opracowano na podstawie sprawozdań z działalności BR z lat 2000-2010. Dane dotyczące liczby wypożyczeń książek beletrystycznych oraz niebeletrystycznych pochodziły z filii ${ }^{4}$ dla dorosłych oraz filii dla dzieci i młodzieży ${ }^{5}$, natomiast udostępnienia zbiorów naukowych ${ }^{6}$ dotyczą dwóch zespołów:

- zespół I - Księgozbioru Podstawowego ${ }^{7}$, Księgozbioru Centralnej Wypożyczalni ${ }^{8}$ oraz zasobu Działu Informacyjno-Bibliograficznego,

- zespół II - zasobu Działu Zbiorów Specjalnych9 Biblioteki Głównej

2 J. Derkaczew, Polacy coraz bardziej nieoczytani, Gazeta Wyborcza [on-line] z dn. 22.02.2009 [dostęp 15 kwietnia 2012]. Dostępny w World Wide Web: http://wyborcza. pl/1,75475,6410206,Polacy_coraz_bardziej_nieoczytani.html.

3 Zob. Czy Polacy czytają? (Dane z raportu: G. Straus, K. Wolff, Czytelnictwo, zakup książek $i$ wykorzystanie Internetu w Polsce w 2006 r.) [on-line]. Księgarnia Internetowa Gandalf [dostęp 15 kwietnia 2012]. Dostępny w World Wide Web: http://www.gandalf. com.pl/wiadomosc/819/.

${ }^{4}$ Do danych pochodzących z filii wliczona została również liczba książek wypożyczonych w punktach bibliotecznych, które zlikwidowano w 2008 r.

${ }^{5}$ W 2010 r. sieć filii Biblioteki Raczyńskich (dalej cyt. BR) miała następującą strukturę: 19 filii dla dorosłych, 12 dla dzieci i młodzieży oraz 18 łączonych (mających w swojej ofercie księgozbiory dla dorosłych oraz dla dzieci i młodzieży). Źródło: Sprawozdanie z działalności BR w 2010 r.

${ }^{6}$ Dane zawierają liczby udostępnień na zewnątrz i na miejscu.

7 W skład Księgozbioru Podstawowego wchodzą: zasób magazynowy, kolekcja Marii i Zygmunta Wojciechowskich, archiwalny zbiór książek dla dzieci (tzw. Archiwum Książki Dziecięcej) oraz księgozbiory podręczne: Czytelni Ogólnej, Działu Zbiorów Specjalnych i Działu Informacyjno-Bibliograficznego. Zob. Z działalności Biblioteki Raczyńskich w Poznaniu w latach 1979-1999, pod red. W. Spaleniaka, Poznań 1999, s. 43-47.

${ }^{8}$ Księgozbiór Centralnej Wypożyczalni ma charakter naukowo-dydaktyczny.

${ }^{9}$ Na zbiory specjalne BR składają się m.in.: rękopisy, stare druki, kartografia, grafika, druki bibliofilskie, dokumenty życia społecznego, nagrania video. Zbiory rękopisów, 
oraz podległych mu zbiorów placówek muzealnych (Muzeum Literackiego Henryka Sienkiewicza, Pracowni-Muzeum Józefa I. Kraszewskiego, Ośrodka Dokumentacji Wielkopolskiego Środowiska Literackiego, Mieszkania-Pracowni Kazimiery Iłłakowiczówny, Izby Pamięci Jerzego Pertka) ${ }^{10}$.

\section{Wypożyczenia książek beletrystycznych}

Po trwającej w latach 2000-2002 względnej stabilizacji wypożyczeń książek beletrystycznych przez czytelników dorosłych: 1338973 wol. w roku 2000 i 1372269 w 2001, w roku 2003 nastąpiło wyraźne zwiększenie wypożyczeń do 1466300 wol., co dało wzrost o 103455 wol. w porównaniu z rokiem poprzednim (zob. wykres 1). Począwszy od roku 2004, liczba wypożyczeń w kolejnych latach badań zmniejszała się, z wyraźnym spadkiem w latach 2008-2010 (odpowiednio 1110 723, 1063127 i 1045789 wol.).

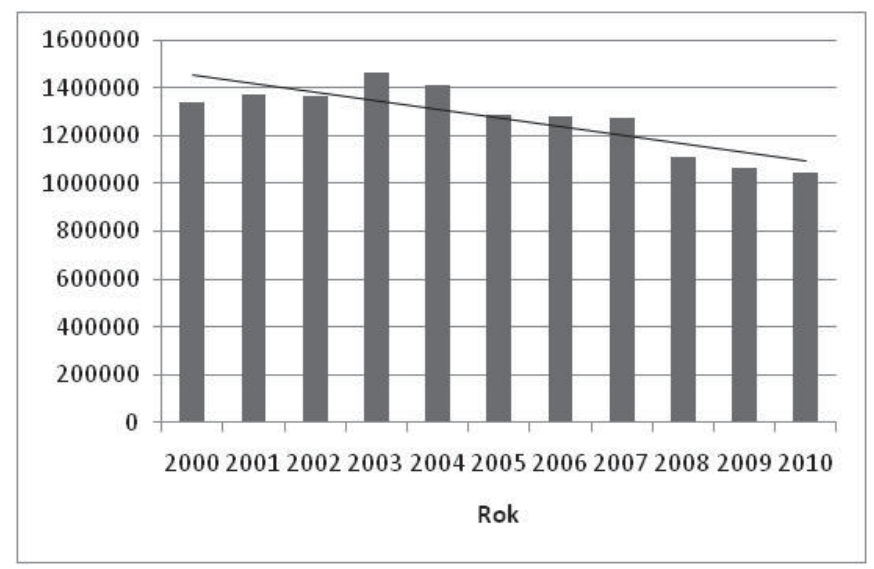

Wykres 1. Wypożyczenia książek beletrystycznych przez czytelników dorosłych w filiach BR w latach 2000-2010

Źródło: Sprawozdania z działalności BR w latach 2000-2010.

starych druków oraz kartografii pochodzą między innymi z przedwojennego zasobu BR i stale są uzupełniane, natomiast gromadzenie zbiorów z pozostałych grup rozpoczęto po II wojnie światowej. Zob. Z działalności Biblioteki Raczyńskich..., s. 47-60.

${ }^{10} \mathrm{~W}$ dniu 31.12.2010 r. w skład BR wchodziły następujące placówki: Biblioteka Główna, 49 filii, Centralna Wypożyczalnia, 5 placówek muzealnych, a także Oddział Biblioteki Raczyńskich w Sapowicach. Por. Sprawozdanie z działalności BR w 2010 r. 
Analiza liczby wypożyczeń książek beletrystycznych w filiach dla dzieci i młodzieży ukazuje, że zarysowują się dwa przeciwstawne okresy cechujące się odmiennymi trendami (por. wykres 2). W latach 2000-2005, mimo wyraźnych fluktuacji, zarysowała się tendencja wzrostowa liczby wypożyczeń (odpowiednio 381293 w 2000 r., 395071 w 2005 r. - co dało wzrost o 13778 wol.). Z kolei lata 2006-2009 cechowało wyraźne obniżenie liczby wypożyczonych woluminów (z 370256 w roku 2006 do 287605 w roku 2009). Korzystnym symptomem jest wzrost liczby wypożyczeń w ostatnim roku badań (2010 r.) o 6473 wol. w porównaniu z rokiem 2009.

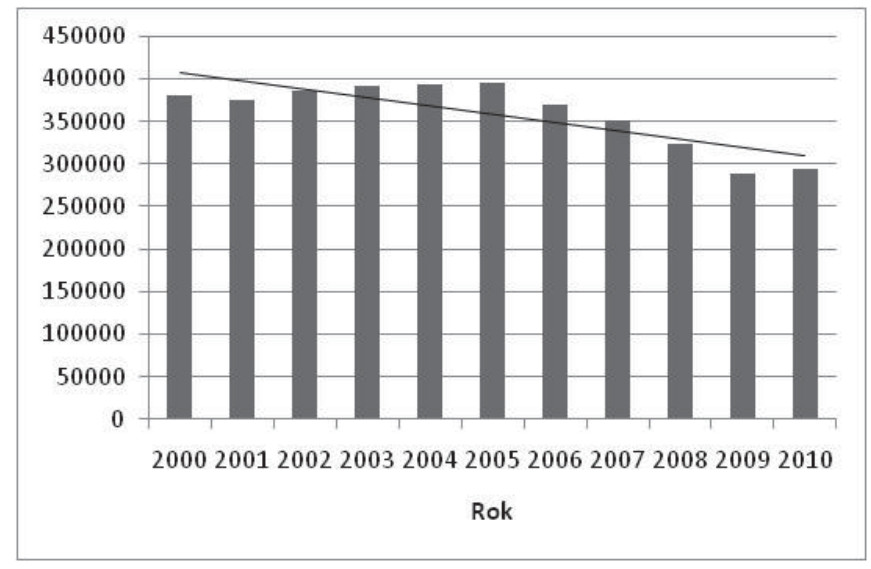

Wykres 2. Wypożyczenia książek beletrystycznych przez czytelników do lat 15 w filiach BR w latach 2000-2010

Źródło: Sprawozdania z działalności BR w latach 2000-2010.

\section{Wypożyczenia książek niebeletrystycznych}

Mimo stwierdzonych w latach 2000-2006 licznych wahań wypożyczeń książek niebeletrystycznych przez czytelników dorosłych, oscylowały one wokół poziomu 400000 wol. (od 407275 w 2002 do 488698 w 2004 r.). Jednakże - podobnie jak w przypadku książek beletrystycznych - również wypożyczenia książek z pozostałych działów uległy wyraźnemu obniżeniu pod koniec minionej dekady. W latach 2007-2010 zarysowała się wyraźna tendencja spadkowa wypożyczeń, z 399851 (2007 r.) do 346816 wol. (2010 r.). Tę tendencję obrazuje wykres 3. 


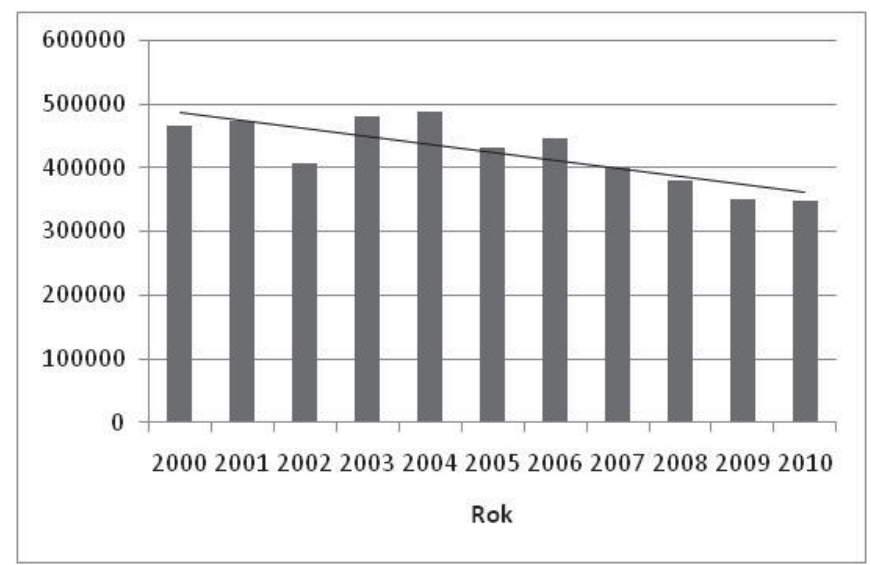

Wykres 3. Wypożyczenia książek niebeletrystycznych przez czytelników dorosłych w filiach BR w latach 2000-2010

Źródło: Sprawozdania z działalności BR w latach 2000-2010.

W latach 2000-2009 odnotowano wyraźny spadek wypożyczeń książek niebeletrystycznych przez dzieci i młodzież (por. wykres 4). Najwięcej woluminów wypożyczono w roku 2000 (110 804), a najmniej w 2009 (65 374) - czyli o 45430 mniej niż na początku dekady. W roku 2010 nastąpił nieznaczny wzrost wypożyczeń - o 941 wol. w stosunku do roku 2009.

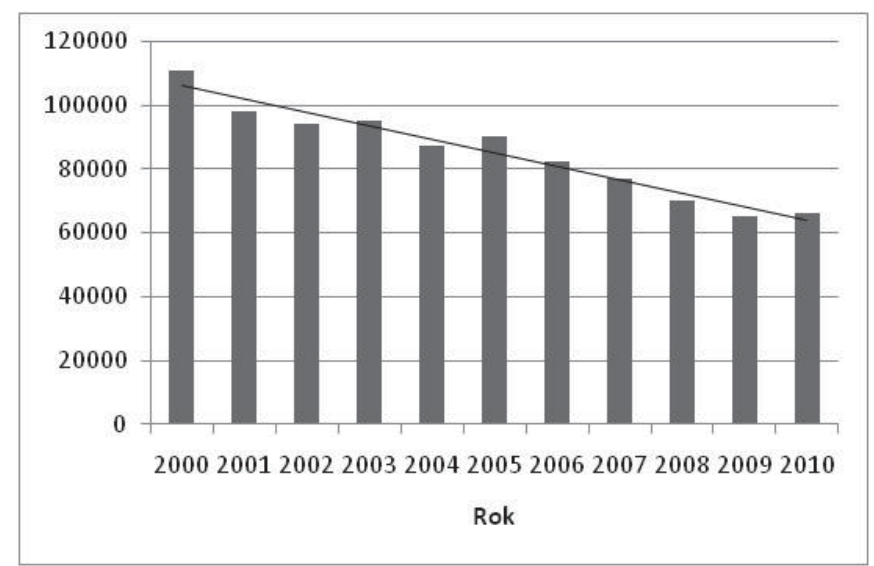

Wykres 4. Wypożyczenia książek niebeletrystycznych przez czytelników do lat $15 \mathrm{w}$ filiach BR w latach 2000-2010

Źródło: Sprawozdania z działalności BR w latach 2000-2010. 
Dzieci i młodzież, podobnie jak czytelnicy dorośli, znacznie chętniej wypożyczali książki beletrystyczne niż pozycje z innych działów. Przeciętnie stosunek wypożyczeń książek beletrystycznych do niebeletrystycznych wynosił $4: 1$ (w przypadku dzieci i młodzieży), a 3:1 (w przypadku osób dorosłych).

\section{Udostępnienia zbiorów naukowych}

W badaniach I zespołu zasobów BR (Księgozbioru Podstawowego, Księgozbioru Centralnej Wypożyczalni, zasobu Działu Informacyjno-Bibliograficznego) odnotowano wzrost udostępnień w latach 2000-2002, a następnie tendencję spadkową do roku $2010^{11} \mathrm{z}$ wyraźnym spadkiem w roku $2007^{12}$. Największą liczbę udostępnień stwierdzono w roku 2002 - 268 793, a najmniejszą w 2010 - 133000 jednostek (zob. wykres 5).

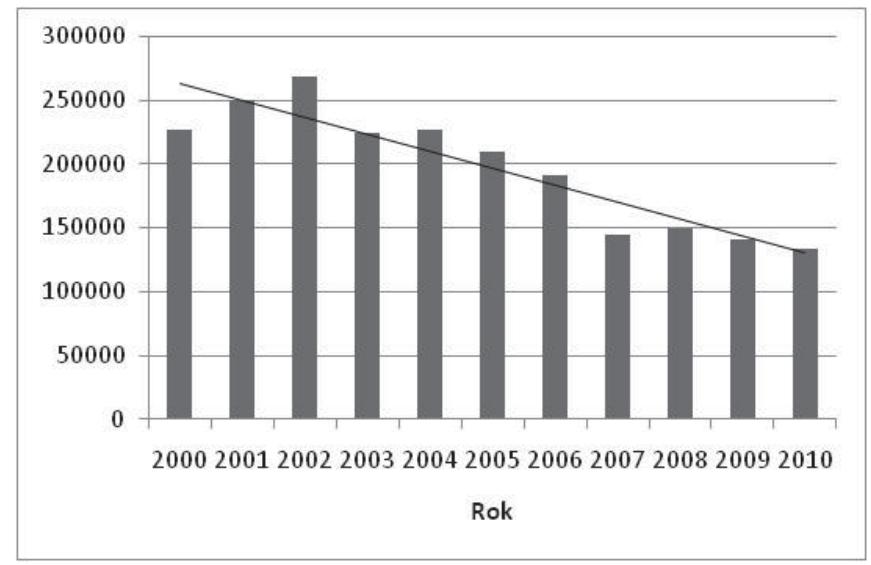

Wykres 5. Udostępnianie zbiorów naukowych w latach 2000-2010 - I zespół Źródło: Sprawozdania z działalności BR w latach 2000-2010.

11 Spadek wypożyczeń i odwiedzin w 2010 r. może być związany z powstaniem dużych bibliotek wydziałowych UAM oraz wyłączeniem części zbiorów BR w czasie przeprowadzki (28.05-21.06) do nowego magazynu.

12 Przyczyną wyraźnego spadku udostępnień w 2007 r. był trwający 3 miesiące remont Czytelni Ogólnej oraz Centralnej Wypożyczalni. 
W badaniach stwierdzono zróżnicowanie udostępnień zbiorów naukowych z II zespołu zasobów Biblioteki (Działu Zbiorów Specjalnych Biblioteki Głównej i podległych mu zbiorów placówek muzealnych). Było ono najmniejsze w latach $2004^{13}, 2007$ i 2009, a wyraźnie większe w latach 2003, 2005, 2006 i 2008, odpowiednio: 7674, 7739, 8412 i 6948 (por. wykres 6). W roku 2010 odnotowano nieznaczny wzrost udostępnień (o 233 jednostki) w porównaniu z rokiem 2009.

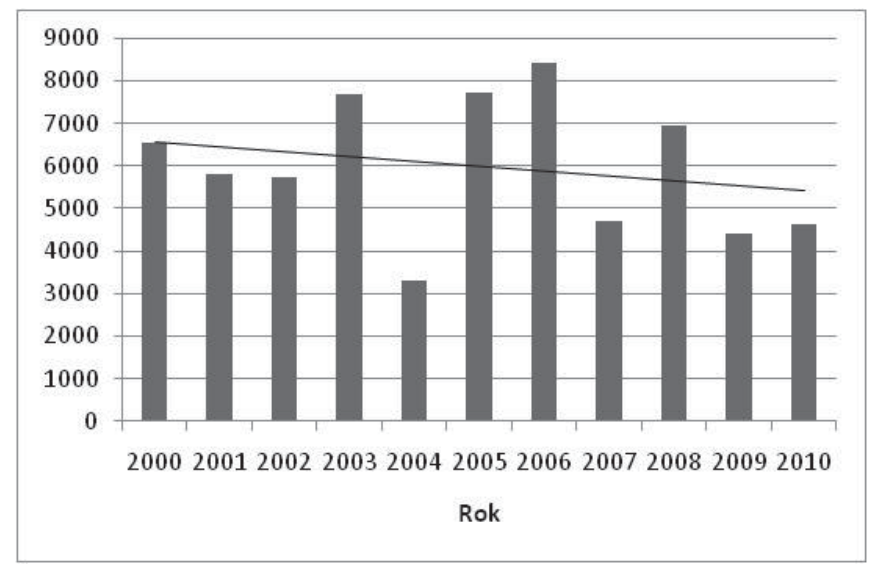

Wykres 6. Udostępnianie zbiorów naukowych w latach 2000-2010 - II zespół Źródło: Sprawozdania z działalności BR w latach 2000-2010.

\section{Dyskusja i wnioski}

W przeprowadzonych badaniach, mimo okresowych wzrostów, stwierdzono tendencję spadkową wypożyczeń książek beletrystycznych, jak i niebeletrystycznych przez czytelników dorosłych oraz dzieci i młodzież. Badane grupy wykazywały większe zainteresowanie książkami beletrystycznymi niż z pozostałych działów. Nie jest to zjawisko nowe, ponieważ - jak podaje Grażyna Straus - od szeregu lat tak kształtuje się ogólny kierunek wyborów lekturowych przez czytelników, którzy w większym stopniu preferują literaturę piękną ${ }^{14}$.

${ }^{13}$ Dane z 2004 r. nie uwzględniają liczby udostępnień z placówek muzealnych.

14 G. Straus, Czytelnictwo 2000: stabilizacja czy stagnacja?, „Bibliotekarz” 2001, nr 7/8, s. 3-6. 
Z obserwacji bibliotekarzy wynika, że jedną z przyczyn spadku wypożyczeń wśród osób uczących się jest sporządzanie notatek dla grupy studentów przez jedną osobę, a następnie udostępnianie ich pozostałym.

Zaobserwowany od 2004 r. spadek wypożyczeń książek beletrystycznych wśród dorosłych może mieć także związek z likwidacją niektórych placówek BR. W roku 2004 BR zredukowała liczbę placówek o 6 filii. W tym to roku, likwidacji największej liczby filii, w porównaniu z rokiem 2003 odnotowano spadek wypożyczeń książek beletrystycznych przez czytelników dorosłych (o 53146 wol.), przy jednoczesnym wzroście wypożyczeń tego typu książek wśród dzieci i młodzieży (o 475 wol.). W przypadku książek niebeletrystycznych zaobserwowano odwrotną zależność: wzrosła liczba wypożyczeń przez czytelników dorosłych (o 9085 wol.), a zmalała wśród dzieci i młodzieży (o 7911 wol.). W kolejnym roku - 2005, w porównaniu z rokiem 2004 - stwierdzono wzrost wypożyczeń książek beletrystycznych (o 2520 wol.) oraz niebeletrystycznych (o 3019 wol.) wśród czytelników do lat 15, a w przypadku czytelników dorosłych odnotowano spadki wypożyczeń literatury beletrystycznej o 126635 wol., a niebeletrystycznej o 57343 wol. Należy podkreślić, iż likwidacja niektórych filii jest zgodna z koncepcją ich reorganizacji i ma na celu stworzenie jednolitej sieci o podobnym, wysokim standardzie zbiorów, usług, lokali oraz wyposażenia. Następnymi krokami ku reorganizacji sieci była likwidacja w latach 2006-2007 dwóch kolejnych filiii ${ }^{15}$.

Badania wykazały także spadek udostępnień w przypadku I zespołu zbiorów naukowych BR - oraz (mimo licznych fluktuacji, ze szczególnie silnym obniżeniem w roku 2004) również w przypadku zespołu II.

Stwierdzona ogólna tendencja spadkowa wypożyczanych książek jest być może związana z niską ogólną liczbą odwiedzin w $\mathrm{BR}^{16}$. Taka tendencja jest zgodna z badaniami przeprowadzonymi w roku 2008 przez Bibliotekę Narodową, przy technicznej współpracy z Ośrodkiem Badania Opinii Publicznej (TNS OBOP), z których wynika, że spadek w polskim czytelnictwie występuje już od kilku lat ${ }^{17}$. Jednak powtórzenie badań w roku 2010 wykazało zatrzymanie tego negatywnego zjawiska ${ }^{18}$.

15 Zob. A. Kleiber, Czytelnictwo w Bibliotece Raczyńskich w latach 2000-2009, „Toruńskie Studia Bibliologiczne" 2011, nr 1 (6), s. 121-131.

16 Tamże.

17 Najniższy poziom czytelnictwa w historii. Rzeczpospolita [on-line] z dn. 20.03.2009 [dostęp 15 kwietnia 2012]. Dostępny w World Wide Web: http://www.rp.pl/artykul/279387.html.

18 R. Chymkowski, Wyłączeni z kultury pisma. Komentarz do badań społecznego zasię- 
Chcąc przeciwdziałać kryzysowi czytelnictwa, BR wyszła naprzeciw nowym oczekiwaniom użytkowników i obok umożliwienia korzystania w filiach z Internetu, zapewnienia dostępu do możliwie najlepszego pod względem ilościowym i jakościowym księgozbioru, oferowania szerokiego i atrakcyjnego wachlarza imprez - dla dzieci i dorosłych ${ }^{19}$, stworzyła także filmoteki, których do roku 2010 powstało $17^{20}$. Obserwując zainteresowanie i reakcje osób odwiedzających filie Biblioteki, należy uznać, że była to decyzja ze wszech miar słuszna, gdyż oferowana przez BR kolekcja filmów cieszyła się i nadal cieszy się dużym zainteresowaniem czytelników. Dzięki niej przyciągnięto wielu nowych użytkowników; w placówkach, które wzbogaciły swoje zbiory o filmy, stwierdzono bowiem zwiększenie się liczby zapisów, odwiedzin oraz wypożyczeń ${ }^{21}$.

Powyższe dane wskazują na to, że aby zachęcić nowych czytelników, biblioteki muszą między innymi uatrakcyjniać oferowane zbiory. Takiego samego zadnia jest Roman Chymkowski ${ }^{22}$ - biblioteki publiczne, jako najważniejsze instytucje umożliwiające kontakt z książką, powinny być pełne atrakcji przyciągających młodych ludzi, którzy niejako mimochodem zainteresują się także czytaniem.

W podsumowaniu niniejszych badań można stwierdzić, że postępujący w ostatnich latach proces unowocześniania życia codziennego, z coraz szerszą możliwością korzystania z elektronicznych form dostępu do informacji (np. Internetu), oddziałuje w wysokim stopniu na strukturę wypożyczeń książek przez wszystkie grupy społeczne. Dorastające społeczeństwo informacyjne będzie wymagać od bibliotek asortymentu usług spełniających jego rosnące oczekiwania, co zapewne będzie determinować strukturę wypożyczeń różnego typu pozycji. Jeśli zależy nam na dostępie czytelników do kultury wyższej, powinniśmy podążać z duchem czasu - a wtedy będziemy czerpać satysfakcję z obsługi bardzo licznej i zadowolonej grupy użytkowników.

gu ksiq̨żki [on-line]. Biblioteka Narodowa [dostęp 15 kwietnia 2012]. Dostępny w World Wide Web: http://www.bn.org.pl/download/document/1297852774.pdf.

19 Zob. A. Kleiber, dz. cyt.

${ }^{20}$ Filmoteki znajdują się w następujących filiach BR: F2, F4, F8, F12, F14, F26, F28,

F38, F50, FW - dla użytkowników dorosłych, oraz dla dzieci i młodzieży w: F2, F14, F26,

F38, F46, F53, F59 - stan na 31 grudnia 2010 r.

${ }^{21}$ Sprawozdanie z działalności Biblioteki Raczyńskich w 2007 r.

22 Zob. R. Chymkowski, dz. cyt. 
The structure of book lending and the usage of scientific collections in the Raczyński library in 2000-2010

ABSTRACT: The article analyses lending of fiction and non-fiction books by adult readers as well readers under 15 years old and the structure of scientific collections usage in the Raczyński Library in 2000-2010. The study shows that in both age groups fiction books were of more interest to the readers than nonfiction books.

KEYWORDS: analyses lending, fiction books, non-fiction books, Raczyński Library, scientific collections usage 